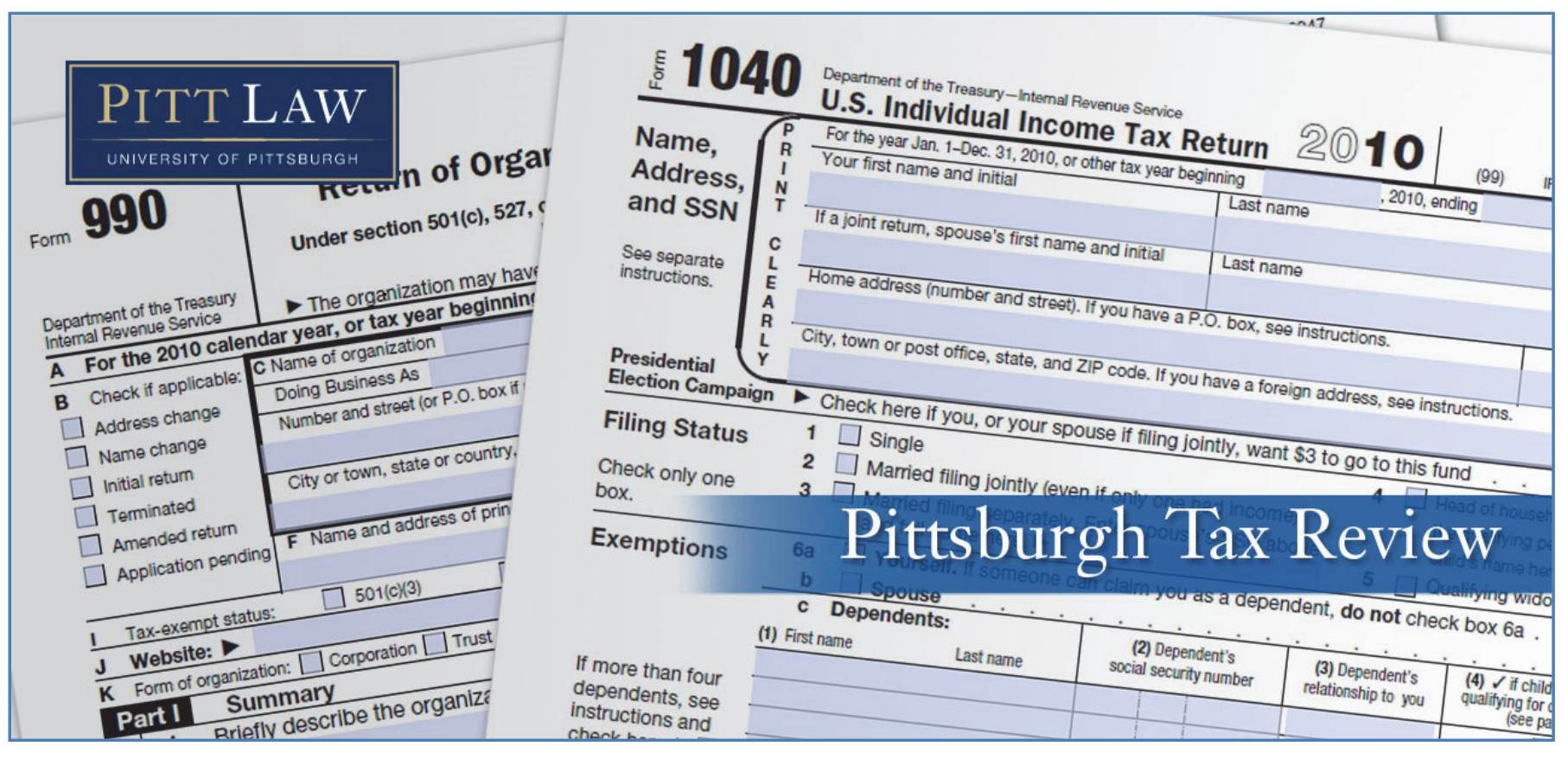

Volume 18 (2020) | ISSN 1932-1821 (print) 1932-1996 (online)

DOI 10.5195/taxreview.2020.124 | http://taxreview.law.pitt.edu

\title{
NOTE
}

\section{VANCOUVER EMPTY HOME TAX: AN ANALYSIS OF TAXATION AS A SOLUTION TO A HOUSING CRUNCH}

\author{
Charles Gallmeyer
}

\section{(cc) EY-NO-ND}

This work is licensed under a Creative Commons Attribution-Noncommercial-No Derivative Works 3.0 United States License.

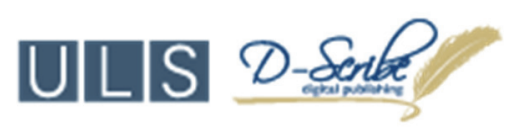

This journal is published by the University Library System of the University of Pittsburgh as part of its D-Scribe Digital Publishing Program, and is cosponsored by the University of Pittsburgh Press. 


\title{
NOTE
}

\section{VANCOUVER EMPTY HOME TAX: AN ANALYSIS OF TAXATION AS A SOLUTION TO A HOUSING CRUNCH}

\author{
Charles Gallmeyer ${ }^{*}$
}

\section{OVERVIEW}

This Note will explore the Vancouver Empty Home Tax, ${ }^{1}$ officially titled Vacancy Tax By-Law No. 11674 ("Empty Home Tax") and its economic impact on the City of Vancouver's rental market. In the Note, I will review the policy justifications for the tax, the effectiveness of this tax regime, similar attempts by cities in the United States, and whether such a tax could be effective in general. The argument will draw upon economic data, government publications, newspaper articles, and current Canadian lawsuits. After reviewing Vancouver's Empty Home Tax, a similar ordinance enacted by the City of Oakland, and past efforts by New York City, this Note will review the constitutionality of such property taxes, suggest a different structure for the Empty Home Tax, and provide an overview of other taxes that could achieve the same ends as an Empty Home Tax. Ultimately, this Note concludes that an Empty Home Tax could be an effective tool for municipal governments to prevent housing bubbles in their jurisdictions, so long as the Empty Home Tax is toggled up and down in a cautious manner in response to market data. To be most effective at achieving

* Candidate for JD, 2021, University of Pittsburgh School of Law. I would like to thank Professors Anthony Infanti and Philip Hackney for their many reviews, suggestions, and edits that made this Note come together. Thank you to all the Pittsburgh Tax Review student editors for their hard work in preparing this Note and this Issue. Finally, thank you to my wife, Katy, who has shown unwavering support as I pursued further education.

${ }^{1}$ VANCOUVER, B.C., VACANCY TAX BY-LAW No. 11674 (2016).

Pitt Tax Review | ISSN 1932-1821 (print) 1932-1996 (online)

DOI 10.5195/taxreview.2020.124 | http://taxreview.law.pitt.edu 


\section{2 |Pittsburgh Tax Review | Vol. 182020}

this end, the Empty Home Tax should limit exemptions and be broadened to a tax on all residences valued over $\$ 1,000,000$.

Vancouver enacted the Empty Home Tax to combat the strain that underutilized housing put on the overall housing market. ${ }^{2}$ With rising rental rates and low rental vacancy rates, Vancouver sought to encourage homeowners to bring underutilized real property back into the rental market. ${ }^{3}$ To do so, the city would levy a $1 \%$ tax on residential properties that were not used as a principal residence for six months of the year. ${ }^{4}$ The levy is now $1.25 \%$, but this Note will review the original Empty Home Tax before several amendments were enacted. ${ }^{5}$ Any proceeds from the tax will benefit affordable housing programs. ${ }^{6}$

The tax, however, has not resulted in a clear-cut victory for curbing Vancouver's housing crisis. ${ }^{7}$ The first year resulted in C\$30 million in tax revenue, ${ }^{8}$ but a vast majority of vacant properties were granted exemptions by government officials. ${ }^{9}$ After the first year of the tax, there were 200 fewer vacant properties (representing a $15 \%$ decrease). ${ }^{10}$ Still, the Vancouver

2 Empty Homes Tax FAQ, CITY OF VANCOUVER, https://vancouver.ca/home-propertydevelopment/empty-homes-tax-frequently-asked-questions.aspx (last visited Mar. 5, 2020). 2019).

${ }^{3}$ City of Vancouver Hous. Vancouver, Empty Homes tax Annual Report 1 (Nov. 1 ,

${ }^{4} I d$.

${ }^{5}$ VANCOUVER, B.C., BY-LAW NO. 12628 (2020).

${ }^{6}$ City of Vancouver Hous. Vancouver, supra note 3, at 6-7.

${ }^{7}$ Andrey Pavlov, Vacancy Tax a Good Idea That's Been Badly Implemented, VANCOUVER SUN (Feb. 1, 2019), https://vancouversun.com/opinion/op-ed/andrey-pavlov-vacancy-tax-a-good-idea-thatsbeen-badly-implemented.

${ }^{8}$ Frances Bula, Vancouver's Empty-Homes Tax to Rake in \$30-Million in First Year; Many Properties Exempted, THE GLOBE AND MAIL (Apr. 23, 2018), https://www.theglobeandmail.com/canada/ british-columbia/article-vancouver-mayor-outlines-effect-of-empty-homes-tax/.

${ }^{9}$ City of Vancouver Hous. Vancouver, supra note 3, at 2.

${ }^{10}$ Adele Peters, Taxing Empty Apartments Could Ease the Housing Crisis, FAST COMPANY (Feb. 12, 2019), https://www.fastcompany.com/90305242/taxing-empty-apartments-could-ease-thehousing-crisis.

Pitt Tax Review | ISSN 1932-1821 (print) 1932-1996 (online) DOI 10.5195/taxreview.2020.124 | http://taxreview.law.pitt.edu 
mayor has recently suggested, and enacted, an increase in the tax. ${ }^{11}$ In an odd side effect to the tax, college students in Vancouver have been enjoying relatively cheap per-bed rent in mansions as homeowners seek to avoid the tax. ${ }^{12}$ Such a use satisfies the law but does not fix the underlying issues the law sought to address because college students living in mansions does not fix either the housing shortage or sky-rocketing rents. Additionally, wealthy individuals have filed suit over the new tax. For example, Chinese millionaires He Yiju and Zheng Jianjing sued the government over a C $\$ 200,000$ tax bill they received for leaving their C $\$ 20.4$ million mansion vacant. ${ }^{13}$

Despite the pending legal issues and limited success, many analysts see the Vancouver Empty Home Tax as a viable tool for solving American housing crises. ${ }^{14}$ Since the Great Recession, American cities have faced significant increases in rent. ${ }^{15}$ Furthermore, rental vacancy rates have steadily decreased in that same time period. ${ }^{16}$ The combination of higher rents and lower availability leave many American cities in a similar position to

${ }^{11}$ See Marcella Bernardo \& The Canadian Press, Vancouver's Mayor Considering Increasing Empty Homes Tax, CityNews 1130 (Feb. 6, 2019), https://www.citynews1130.com/2019/02/06/ vancouver-empty-homes-tax-increase/; BY-LAW No. 12628, supra note 5.

${ }^{12}$ Natalie Wong \& Natalie Obiko Pearson, College Kids Are Living Like Kings in Vancouver's Empty Mansions, BlOOMBERG (Apr. 16, 2019), https://www.bloomberg.com/news/features/2019-0416/college-kids-are-living-like-kings-in-vancouver-s-empty-mansions.

${ }^{13}$ Joshua Berlinger, Wife of Chinese Multimillionaire Sues Over \$200,000 Fine for Not Living in $\$ 20 M$ Vancouver Mansion, CNN (July 10, 2019), https://www.cnn.com/2019/07/10/asia/vancouver-taxchina-he-yiju-intl-hnk/index.html.

${ }^{14}$ See Peters, supra note 10; Pramod Sukumaran, Can Taxing Empty Apartments Help the Affordable Housing Crisis?, SALUD AMERICA! (June 7, 2019), https://salud-america.org/can-taxingempty-apartments-help-the-affordable-housing-crisis/.

${ }^{15}$ Sewin Chan \& Gita Khun Jush, 2017 National Rental Housing Landscape, NYU FURMAN CENTER, https://furmancenter.org/files/NYUFurmanCenter_2017_National_Rental_Housing_Landscape 04OCT2017.pdf.

${ }^{16}$ U.S. CENSUS BuREAU, QUARTERLY RESIDENTIAL VACANCIES AND HOMEOWNERSHIP, FOURTH QUARTER 2019, CB20-05 (Jan. 30, 2020), https://www.census.gov/housing/hvs/files/qtr419/Q419press .pdf.

Pitt Tax Review | ISSN 1932-1821 (print) 1932-1996 (online) DOI 10.5195/taxreview.2020.124 | http://taxreview.law.pitt.edu 
Vancouver. Some U.S. cities have looked to emulate Vancouver's Empty Home Tax, ${ }^{17}$ including Los Angeles ${ }^{18}$ and Oakland, California. ${ }^{19}$

Taxing homeowners who let a residence sit idle forces them to foot the social cost of their behavior. ${ }^{20}$ In theory, homeowners who sit on multiple properties contribute to housing scarcity and the rise in rents. ${ }^{21}$ A Pigouvian $\operatorname{tax}^{22}$ like the Vancouver Empty Home Tax would force these homeowners to bear the brunt of the cost attributed to their behavior. ${ }^{23}$ To decide if such a tax would be successful in American cities, this Note will review the set-up of the Vancouver Empty Home Tax, its early successes and failures, and the similarities and differences in economic data between selected American cities and Vancouver.

${ }^{17}$ Dave McAfee, U.S. Cities Look to Vancouver's Novel Empty Homes Tax, BloOMBERG TAX (July 24, 2019), https://news.bloombergtax.com/daily-tax-report-state/u-s-cities-look-to-vancouversnovel-empty-homes-tax.

${ }^{18}$ Emily Alpert Reyes \& Andrew Khouri, L.A. Council Members Propose Taxing Landlords Who Leave Homes Vacant, L.A. Times (June 11, 2019), https://www.latimes.com/local/lanow/la-me-lnvacant-housing-tax-rental-homeless-crisis-20190611-story.html.

${ }^{19}$ Kathleen Pender, Oakland's Vacant-Property Tax Takes Effect, Sparking Hope-and Alarm, S.F. CHRON. (Jan. 26, 2019), https://www.sfchronicle.com/business/networth/article/Oakland-s-vacantproperty-tax-takes-effect-13563273.php.

${ }^{20}$ See generally Robert H. Frank, Heads, You Win. Tails, You Win, Too., N.Y. TimES (Jan. 5, 2013), https://www.nytimes.com/2013/01/06/business/pigovian-taxes-may-offer-economic-hope.html (detailing how a buyer of a large car could foot the social cost of that large car via a Pigouvian tax).

${ }^{21}$ Holden Lewis, Housing Shortage: 6 Reasons Not Enough Homes Are for Sale, NERDWALLET (Dec. 17, 2019), https://www.nerdwallet.com/blog/mortgages/6-reasons-there-arent-enough-homes-forsale/.

${ }^{22}$ A Pigouvian tax attempts to regulate actions with negative externalities by recouping the costs of the actor's actions. For example, when an entity creates a negative externality like environmental pollution, the government may try to tax the entity at a level that covers the cost of cleaning up the pollution. See Ellen P. Aprill, The Private Foundation Excise Tax on Self-Dealing: Contours, Comparisons, and Character, 17 PITT. TAX REV. 297, 325 (2020).

${ }^{23}$ Nadav Shoked, Cities Taxing New Sins: The Judicial Embrace of Local Excise Taxation, 79 Оніо ST. L.J. 802 (2018).

Pitt Tax Review | ISSN 1932-1821 (print) 1932-1996 (online)

DOI 10.5195/taxreview.2020.124 | http://taxreview.law.pitt.edu 


\section{STRUCTURE OF THE VANCOUVER STATUTE}

The basics of the Empty Home Tax are relatively simple. Overall, the Empty Home Tax enacted by the City of Vancouver includes ten sections. ${ }^{24}$ The sections define the tax, exemptions, administration, complaints and review process, and penalties. ${ }^{25}$ The definition of vacant property is short and concise, ${ }^{26}$ and the vacancy tax and the tax rate take up, in total, two sentences. ${ }^{27}$

Section 2.1 provides that "[a] vacancy tax shall be imposed on every parcel of taxable property in accordance with this By-law." 28 Sections 2.2, 2.3, and 2.4 further define what "vacancy" means. ${ }^{29}$ A residential property is deemed vacant under two circumstances: (1) the property has been unoccupied for more than six months during the calendar year or (2) the code provides that the property is a vacant property. ${ }^{30}$ According to section 2.2, a residential property is considered unoccupied in two instances: (1) the residential property is not the principal residence ${ }^{31}$ of the owner; or (2) the residential property is not occupied by a tenant or subtenant for a term of thirty consecutive days. ${ }^{32}$ Thus, a residential property is a vacant property if it has been unoccupied for more than six months, ${ }^{33}$ and any second home or rental property that is not occupied by a tenant for, on aggregate, six months

\footnotetext{
${ }^{24}$ VACANCY TAX BY-LAW No. 11674, supra note 1.

${ }^{25} \mathrm{Id}$.

${ }^{26} I d . \S 2.2-.3$.

${ }^{27} I d . \S \S 2.1,2.4$.

${ }^{28} I d . \S 2.1$.

${ }^{29} I d . \S 2.2-.4$.

${ }^{30} I d . \S 2.3$.

31 "Principal Residence" is defined in $\S 1.2$ as "the usual place where an individual lives, makes his or her home and conducts his or her daily affairs, including, without limitation, paying bills and receiving mail, and is generally the residential address used on documentation related to billing, identification, taxation and insurance purposes, including, without limitation, income tax returns, Medical Services Plan documentation, driver's licenses, personal identification, vehicle registration and utility bills and, for the purposes of this by-law, a person may only have one principal residence."

${ }^{32} I d . \S 2.2$.

${ }^{33} \mathrm{Id}$.
}

Pitt Tax Review | ISSN 1932-1821 (print) 1932-1996 (online) DOI 10.5195/taxreview.2020.124 | http://taxreview.law.pitt.edu 


\section{6 | Pittsburgh Tax Review | Vol. 182020}

out of the year is deemed a vacant property. ${ }^{34}$ In such a situation, the City of Vancouver will levy a tax of $1 \%$ (now $1.25 \%$ ) of the value of the vacant residential property. ${ }^{35}$ Failure to pay the vacancy tax results in a flat penalty of $5 \% .^{36}$

The bill allows for homeowners to claim exemptions to avoid paying the tax. ${ }^{37}$ These exemptions include: (1) death of the registered owner, (2) property undergoing redevelopment or major renovations, (3) property of an owner who is in care, (4) rental restriction or prohibition, (5) transfer of property, (6) occupancy for full-time employment, (7) court order, and (8) limited-use residential property. ${ }^{38}$ These exemptions prevent the vacancy tax from being levied in many instances; for example, the tax will not be levied if the property is vacant for more than six months because the owner is receiving care at a hospital, ${ }^{39}$ the property is not the principal residence of the owner but required because the owner works in Vancouver, ${ }^{40}$ and the property is limited to vehicle parking or otherwise cannot be used for residential purposes. ${ }^{41}$ Furthermore, section 3.2, perhaps the most complicated of the exemptions, allows an exemption when a property owner is conducting major renovations to the property. ${ }^{42}$ This exemption has three requirements for homeowners who are renovating: A residential property can be vacant for more than six months if the property is vacant in order to (1) "safely carry out major renovations" that have been (2) permitted by the city and (3) are being completed in a timely manner. ${ }^{43}$ Additionally, section 3.2(b) and (c) allow this exemption for "[p]roperty undergoing redevelopment or major renovations" to apply in instances where a rezoning,

\footnotetext{
${ }^{34} I d$.

${ }^{35} I d . \S 2.4$.

${ }^{36} I d$. $\$ 2.7-.8$.

${ }^{37}$ Id. $\S 3.1-.8$.

${ }^{38} \mathrm{Id}$.

${ }^{39} I d . \S 3.3$.

${ }^{40} I d . \S 3.6$.

${ }^{41} I d . \S 3.8$.

${ }^{42} I d . \S 3.2$.

${ }^{43} I d . \S 3.2(\mathrm{a})$.
}

Pitt Tax Review | ISSN 1932-1821 (print) 1932-1996 (online) DOI 10.5195/taxreview.2020.124 | http://taxreview.law.pitt.edu 
development permit, or heritage alteration permit application has been submitted by the property owner and the residential property is "unimproved with any dwelling units." 44

Section 5 of the Empty Home Tax details the responsibilities of the owner. ${ }^{45}$ The law requires that Vancouver residential property owners submit an annual "property status declaration" to the Collector of Taxes before the second business day of February. ${ }^{46}$ In this declaration, the owner either claims the property is a principal residence, claims an exemption, or attests that the property is vacant. ${ }^{47}$

If, after a property owner submits a property status declaration, the Collector of Taxes files a vacancy tax notice, ${ }^{48}$ the property owner then has an opportunity to contest the tax via a notice of complaint. ${ }^{49}$ A complaint may be made on two grounds: (1) an error or omission on the part of the city or (2) an error or omission on the part of the registered owner in filing the property status declaration. ${ }^{50}$ The notice of complaint must include: (1) identification of the residential property; (2) full name of the complainant; (3) contact information for the complainant; (4) identification of whether the complainant is the registered property owner; (5) the reason for the complaint; and (6) identification of the reason, including evidentiary support, for why the vacancy tax should not be imposed. ${ }^{51}$ Once the complaint is submitted, a vacancy tax review officer must review the complaint within an undefined "reasonable" time. ${ }^{52}$ After completing review

\footnotetext{
${ }^{44} I d . \S 3.2(\mathrm{~b})-(\mathrm{c})$.

${ }^{45} I d . \S 5$.

${ }^{46} I d . \S 5.1-.2$.

${ }^{47} I d . \S 5.4$.

${ }^{48} I d . \S \S 1.2,4.13$.

${ }^{49} I d . \S \S 1.2,6.2$.

${ }^{50} \mathrm{Id}$ § 6.2 .

${ }^{51} I d . \S 6.4$.

${ }^{52} I d . \S 6.7$.
}

Pitt Tax Review | ISSN 1932-1821 (print) 1932-1996 (online) DOI 10.5195/taxreview.2020.124 | http://taxreview.law.pitt.edu 


\section{8 |Pittsburgh Tax Review | Vol. 182020}

of the complaint, the vacancy tax review officer must send a determination to the property owner. ${ }^{53}$

A property owner may contest the officer's determination through review by a vacancy tax review panel. ${ }^{54}$ The property owner has 30 days to submit a review request to the vacancy tax review panel. ${ }^{55}$ The review request must include similar information to the notice of complaint. ${ }^{56}$ This information includes: (1) identification of the residential property at issue; (2) identification of the individual requesting the review, including contact information; (3) whether the requestor is the registered homeowner; and (4) the grounds upon which the review is requested. ${ }^{57}$ The vacancy tax review panel must consider the review request within a reasonable time. ${ }^{58}$ The determination of the vacancy tax review panel is final and no avenues to appeal exist. $^{59}$

A property owner who does not comply with the Empty Home Tax may be penalized. ${ }^{60}$ A person is deemed to be in violation of the Empty Home Tax if they: (1) violate any provision of the by-law; (2) fail or abstain from performing any action required by the by-law; or (3) do not comply with an "order, direction, or notice" pertaining to the by-law. ${ }^{61}$ The penalty for violations is "a fine of not less than $\$ 250.00$ and not more than $\$ 10,000.00$ for each offence."

The Empty Home Tax, while simple and concise in itself, increases considerably in complexity as its exemptions are considered, raising

\footnotetext{
${ }^{53} I d . \S 6.8$.

${ }^{54} I d . \S 6.9$.

${ }^{55} \mathrm{Id} . \S 6.11$.

${ }^{56} I d . \S \S 6.4,6.12$.

${ }^{57}$ Id. $\S 6.12$.

${ }^{58} I d . \S 6.14$.

${ }^{59} I d . \S 6.15$.

${ }^{60} I d . \S 8$.

${ }^{61} I d . \S 8.1$.

${ }^{62}$ Id. § 8.2.
}

Pitt Tax Review | ISSN 1932-1821 (print) 1932-1996 (online) DOI 10.5195/taxreview.2020.124 | http://taxreview.law.pitt.edu 
questions about the impact on administrability of the tax. ${ }^{63}$ The exemptions necessarily lessen the impact the tax has on the rental market and on the city's budget. $^{64}$

\section{MiXED RESULTS}

The tax has seen some successes and failures. According to the Empty Homes Tax Annual Report, measuring the successes and failures of the tax is challenging. ${ }^{65}$ In 2018 , the City of Vancouver raised C $\$ 41.2$ million in revenue from the tax and penalty provisions of the Empty Home Tax. ${ }^{66}$ However, only C $\$ 23.3$ million of that has been collected. ${ }^{67}$ This is a slight decrease as compared to the $\mathrm{C} \$ 33.6$ million collected on the $\mathrm{C} \$ 39.1$ million levied in $2017 .{ }^{68}$ A vast majority of the revenue raised in 2018 was from the audit process. ${ }^{69}$ Sections 4.11 and 4.12 of the Empty Home Tax allow the tax administrator to audit residences to ensure that property owners are in compliance with the Empty Home Tax. ${ }^{70}$ Noncompliant property owners are assessed the tax. ${ }^{71}$ This adds to the cumbersome nature of the administration of the tax because of the time, cost, and complexity created by an audit process. In 2018, the Vancouver City Council requested input on how to spend initial Empty Home Tax revenue of C $\$ 8$ million, ${ }^{72}$ which is starkly less than the C\$33.6 million reportedly collected in 2017 and $C \$ 23.3$ million

${ }^{63}$ See Pavlov, supra note 7.

${ }^{64}$ See id.

${ }^{65}$ City of VAncouver Hous. VAnCouver, supra note 3.

${ }^{66}$ See id. at 4.

${ }^{67} \mathrm{Id}$.

${ }^{68}$ See id.

${ }^{69} I d$. ("Revenue generated from audit activities during the period from November 2, 2018 to November 1, 2019 was \$22.1 million.”).

${ }^{70}$ VACANCY TAX BY-LAW No. 11674, supra note 1, § 4.11-.12.

${ }^{71} I d . \S 4.12$.

${ }^{72}$ City of VANCOUVER Housing VANCOUVER, supra note 3, at 6.

Pitt Tax Review | ISSN 1932-1821 (print) 1932-1996 (online) DOI 10.5195/taxreview.2020.124 | http://taxreview.law.pitt.edu 


\section{$200 \mid$ Pittsburgh Tax Review | Vol. 182020}

reportedly collected in $2018 .^{73}$ This suggests high implementation costs, high audit costs, or inaccurate reporting.

Additionally, the number of exempt and vacant properties have both decreased since $2017 . .^{74}$ Properties declared exempt have decreased $21 \%$, from 5,383 exempt properties in 2017 to 4,256 exempt properties in $2018 .^{75}$ Vacant properties have decreased by 549 properties, or a $22 \%$ decrease. $^{76}$ Combined, vacant and exempt properties represent $3.3 \%$ of all available residential property in Vancouver in $2018 .{ }^{77}$ Most of these properties (i.e., $68 \%$ ) are exempt properties, which means that $2.2 \%$ of all available residential property in Vancouver was exempt from the vacancy tax in $2018 .^{78}$ Granting so many exemptions to the Empty Home Tax does nothing to add these properties back to the rental market. Many of the exemptions provide for temporary relief, and thus may eventually add these residences back to the rental market, or free up rentals when homeowners return to their principal residences.

The City of Vancouver does have evidence that properties previously declared vacant have been returned to the rental market. ${ }^{79}$ In $2017,2,538$ properties were declared vacant. ${ }^{80}$ Of those, 1,199 were being used as a residence in 2018 , which means that $47 \%$ of the 2017 vacant properties were being utilized in $2018 .^{81}$ Of these, 641 properties were placed on the rental market and tenanted. ${ }^{82}$ Therefore, the empty homes tax may have contributed to adding these properties back to the rental market. Overall, 3,332 tenanted

\footnotetext{
${ }^{73}$ See id. at 4.

${ }^{74}$ See id. at 2.

${ }^{75} \mathrm{Id}$.

${ }^{76} \mathrm{Id}$. (declaring 2,538 properties vacant in 2017 versus 1,989 properties vacant in 2018).

${ }^{77} \mathrm{Id}$. at 9.

${ }^{78} I d$. at 10

${ }^{79}$ See id. at 9.

${ }^{80} \mathrm{Id}$.

${ }^{81} \mathrm{Id}$.

${ }^{82}$ Id.
}

Pitt Tax Review | ISSN 1932-1821 (print) 1932-1996 (online) DOI 10.5195/taxreview.2020.124 | http://taxreview.law.pitt.edu 
properties were added to the City of Vancouver's rental market in $2018 .^{83}$ Presumably, this number includes newly constructed tenanted properties and other types of property that would not count as returned to the market via the Empty Home Tax.

Lawsuits have popped up over the administration of the tax as well. For example, as mentioned earlier, He Yiju and Zheng Jianjing are suing the City of Vancouver over their Empty Home Tax bill because they claim they were exempt under section 3.2 as their property was in redevelopment. ${ }^{84}$ The couple bought their Vancouver mansion in 2015 and filed a property status declaration in 2018 for the 2017 tax year. ${ }^{85}$ In 2017, He Yiju and Zheng Jianjing filed for city redevelopment permits. ${ }^{86}$ The City of Vancouver did not grant those permits until 2019, and therefore issued a tax bill for the year 2017. ${ }^{87}$ The Empty Home Tax does not account for such lagged permitting processes $;{ }^{88}$ this suggests a gap in the drafting of the code, which contributes to the complicated nature of the Empty Home Tax. Such legal issues could make the Vancouver Empty Home Tax less effective, and these issues may undermine public support for the tax as homeowners feel unfairly victimized by a code provision they attempted to adhere to.

Furthermore, the Empty Home Tax may be targeting properties that do not add value to the rental market. For example, the average assessed value of a vacant condominium is $\mathrm{C} \$ 1.4$ million. ${ }^{89}$ This is $53 \%$ higher than the average assessed value of a Vancouver condominium, which is $\mathrm{C} \$ 900,000 .^{90}$ The average assessed value of a vacant single-family home is C\$3.4 million - more than $40 \%$ higher than Vancouver's average assessed value for

\footnotetext{
${ }^{83} I d$.

${ }^{84}$ Keith Fraser, Owner of \$24 Million Point Grey Home Goes to Court to Fight \$294,000 Vacancy Tax Bill, VANCOUVER SuN (June 25, 2019), https://vancouversun.com/news/local-news/owner-of-24million-point-grey-home-goes-to-court-to-fight-249-k-vacancy-tax-bill.

${ }^{85} \mathrm{Id}$.

${ }^{86} \mathrm{Id}$.

${ }^{87} \mathrm{Id}$.

${ }^{88} \mathrm{Id}$.

${ }^{89}$ City of VAnCouver Hous. VANCOUVER, supra note 3, at 9.

${ }^{90} \mathrm{Id}$.
}

Pitt Tax Review | ISSN 1932-1821 (print) 1932-1996 (online) DOI 10.5195/taxreview.2020.124 | http://taxreview.law.pitt.edu 


\section{Pittsburgh Tax Review | Vol. 182020}

a single-family home (C\$2.4 million). ${ }^{91}$ This indicates that the vacant properties are high-value residences. Adding these back to the rental market would not benefit the lower- and middle-class workers who are squeezed out by the tight rental market; only the wealthy could afford the rental rates on such properties. This has led to owners of mansions renting out the residence by the room to college students. ${ }^{92}$

Homeowners eager to avoid the new Empty Home Tax have turned to renting mansions by the bedroom to undergraduates at nearby universities. ${ }^{93}$ In mid-2019, prices on Vancouver homes were down nearly $8.5 \%$ off the high price, leaving many owners in a bind: either sell at a loss or rent on the cheap to avoid additional taxes. ${ }^{94}$ This results in college students living like "kings" 95 in fancy mansions, with amenities like billiards tables, steam rooms, and glass chandeliers. ${ }^{96}$ One nine-bedroom mansion, supposedly owned by an Afghani pop musician, ${ }^{97}$ is rented to fourteen students at $\mathrm{C} \$ 825$ per bed per month. ${ }^{98}$ For comparison, in 2018, a one-bedroom apartment in Vancouver averaged C\$2,100 per month and a two-bedroom apartment averaged $\mathrm{C} \$ 3,300 .{ }^{99}$ Returning mansions to the rental market so that the properties can be rented to college students does little to ease the strain on the overall rental market. College students are an inherently transient population. Returning properties to the rental market to be rented by college students does not enable working class citizens to rent within the City of Vancouver.

\footnotetext{
${ }^{91} I d$.

${ }^{92}$ Wong \& Obiko Pearson, supra note 12.

${ }^{93} \mathrm{Id}$.

${ }^{94} \mathrm{Id}$.

${ }^{95} \mathrm{Id}$.

${ }^{96} I d$.

${ }^{97} \mathrm{Id}$.

${ }^{98} I d$.

${ }^{99}$ Vancouver's Average Rental Price for One-Bedroom Apartment Jumps to \$2,100, VANCOUVER SuN (Oct. 15, 2018), https://vancouversun.com/news/local-news/vancouvers-average-rental-price-forone-bedroom-apartment-jumps-to-2100.
}

Pitt Tax Review | ISSN 1932-1821 (print) 1932-1996 (online) DOI 10.5195/taxreview.2020.124 | http://taxreview.law.pitt.edu 
The City of Vancouver's Empty Homes Tax Annual Report points to successes in returning vacant properties to the rental market and in revenue generation. ${ }^{100}$ However, the Empty Home Tax only affects $1.1 \%$ of the total residential properties in the City of Vancouver. ${ }^{101}$ And of that $1.1 \%$ of properties, the high assessed values seems to indicate that the properties would not contribute much to revitalizing the market for affordable or midtier housing upon being returned to Vancouver's rental market. ${ }^{102}$ Nevertheless, the 2016 Vancouver rental market had a vacancy rate of $1 \%$, ${ }^{103}$ suggesting that returning even $1.1 \%$ in such a tight market might have a significant impact. Lawsuits surrounding the administrability of the Empty Home Tax have called into question the fairness and feasibility of applying the tax. Several years in, the Empty Home Tax has had some successes. Revenue from the tax as well as other allocations from the Vancouver City Council have gone to supporting and improving cooperative housing, increasing the supply of shelter beds, and supporting renters via "renters advocacy and services" and a "rent bank." 104 The Vancouver Rent Bank provides assistance to the city's low-income housing population via one-time interest free loans and referral services. ${ }^{105}$ Such financial support surely helps the low- and middle-income populations in Vancouver; however, these funds do not address the stated goal of returning vacant properties to the market. ${ }^{106}$ It may be too soon to determine whether these successes have eased the tight rental market in Vancouver.

\footnotetext{
${ }^{100}$ City of Vancouver Hous. Vancouver, supra note 3, at 4, 9.

${ }^{101}$ Id. at 9 ("In 2018, 1,989 properties (approximately 1.1\% of all properties) were vacant ...").

${ }^{102} I d$. ("Vacant property has a higher assessed value than properties overall.").

${ }^{103} I d$. at 1 .

${ }^{104} \mathrm{Id}$. at 7 .

${ }^{105}$ Vancouver Rent Bank, CITY OF VANCOUVER, https://vancouver.ca/people-programs/financialaid.aspx (last visited Aug. 20, 2020).

${ }^{106}$ City OF VAnCouver Hous. VAnCouver, supra note 3, at 1 ("The City of Vancouver created the Empty Homes Tax (EHT), also known as the Vacancy Tax, to help return empty and under-utilized properties to the market as long-term rental homes for people who live and work in Vancouver as just one of the many actions in its 10-year Housing Vancouver Strategy.").
}

Pitt Tax Review | ISSN 1932-1821 (print) 1932-1996 (online) DOI 10.5195/taxreview.2020.124 | http://taxreview.law.pitt.edu 


\section{4 |Pittsburgh Tax Review | Vol. 182020}

\section{COMPARISON TO OTHER NORTH AMERICAN CITIES}

According to the Empty Homes Tax Annual Report, 53\% of Vancouver households rent instead of own, citing to data compiled in $2016 .{ }^{107}$ Combined with the extremely low vacancy rate of $1 \%,{ }^{108}$ these issues make Vancouver one of the most expensive Canadian cities to live in. ${ }^{109}$ The tight rental market creates difficulties for those with low income to live and work in the city. ${ }^{110}$ The City of Vancouver passed the Empty Homes Tax in order to combat this problem by returning underutilized residential properties to the rental market to help ease the strain. ${ }^{11}$

Vancouver's tight rental market is not alone. Facing similar predicaments, many American cities have looked to the Vancouver Empty Home Tax as a potential model. Cities like Oakland, ${ }^{112}$ Los Angeles, ${ }^{113}$ San Diego, California ${ }^{114}$ and Honolulu, Hawaii ${ }^{115}$ have all explored implementing a similar tax with similar policy justifications. Using the early results from Vancouver (\$30 million raised, ${ }^{116}$ returning 1,199 vacant residential properties to the rental market, ${ }^{117}$ and a significant proportion of properties claiming exemptions ${ }^{118}$ ), this Note will examine economic data and laws of

\footnotetext{
${ }^{107} I d$.

${ }^{108} I d$.

${ }^{109}$ Id. ("Vancouver's rental housing market, which at less than $1 \%$ rental vacancy rate, has among the lowest rental vacancy rates and the highest rental costs of any Canadian city.").

${ }^{110} \mathrm{Id}$.

${ }^{111}$ Id. ("The City of Vancouver created the Empty Homes Tax (EHT), also known as the Vacancy Tax, to help return empty and under-utilized properties to the market as long-term rental homes for people who live and work in Vancouver as just one of the many actions in its 10-year Housing Vancouver Strategy.").

${ }^{112}$ Pender, supra note 19.

${ }^{113}$ Reyes \& Khouri, supra note 18.

${ }^{114}$ McAfee, supra note 17.

${ }^{115} I d$.

${ }^{116}$ City OF VANCOUVER Hous. VANCOUVER, supra note 3, at 4.

${ }^{117} I d$. at 9.

${ }^{118}$ Id. at 2 (In 2018, 4,256 residential properties were declared exempt while 1,989 residential properties were declared vacant.).
}

Pitt Tax Review | ISSN 1932-1821 (print) 1932-1996 (online) DOI 10.5195/taxreview.2020.124 | http://taxreview.law.pitt.edu 
a few major American metropolitan areas to determine if such a tax is worthwhile from revenue generation, incentivization, and administration standpoints.

As of 2018, the national vacancy rate for rental housing in the United States was $6.4 \%{ }^{119}$ This pales in comparison to the $11 \%$ rate seen during the peak of the Great Recession. ${ }^{120}$ More granular data at the metropolitan level also does not show any area with nearly as tight a rental market as Vancouver. For example, in 2018 the rental vacancy rate in the Los Angeles/Long Beach/Anaheim metropolitan area was $4.0 \%{ }^{121}$ Likewise, the New York/Newark/Jersey City metropolitan area had a $4.5 \%$ vacancy rate. ${ }^{122}$ Furthermore, the San Francisco/Oakland/Hayward metropolitan area had a rental vacancy rate of $5.4 \% .{ }^{123}$ These three metropolitan areas are frequently cited as some of the most expensive rental markets in the United States, ${ }^{124}$ and yet none face the same market that Vancouver did when it passed the Empty Home Tax. Unfortunately, the U.S. Census Bureau does not provide vacancy statistics that focus in on the individual cities like New York, San Francisco, and Oakland. ${ }^{125}$ Presumably, these cities that anchor the metropolitan area would have lower vacancy rates more on par with Vancouver.

Because these statistics only cover the metropolitan level, municipality numbers could be much tighter. For example, in Oakland, out of approximately 112,000 parcels of land, around $4 \%$ sit vacant. ${ }^{126}$ In response

${ }^{119}$ U.S. CENSUS BUREAU, supra note 16.

${ }^{120} I d$.

${ }^{121}$ U.S. Census Bureau, Housing VaCANCies and Homeownership, ANNUAl Statistics: 2018, Table 6, https://www.census.gov/housing/hvs/data/ann18ind.html.

${ }^{122} \mathrm{Id}$.

${ }^{123} \mathrm{Id}$.

124 JD Esajian, Rent Report: Highest Rent in US 2019, FORTUNEBUILDERS, https://www .fortunebuilders.com/top-10-u-s-cities-with-the-highest-rents/ (last visited July 12, 2020).

${ }^{125}$ U.S. CENSUS BUREAU, supra note 16.

${ }^{126}$ Steven Tavares, Oakland's Vacant Lot Tax Sowing Confusion, EAST BAY EXPRESS (Oct. 2, 2019), https://www.eastbayexpress.com/oakland/oaklands-vacant-lot-tax-sowing-confusion/Content?oid $=27680727 \&$ showFullText $=$ true.

Pitt Tax Review | ISSN 1932-1821 (print) 1932-1996 (online) DOI 10.5195/taxreview.2020.124 | http://taxreview.law.pitt.edu 


\section{6 |Pittsburgh Tax Review | Vol. 182020}

to this vacant lot issue, Oakland residents passed Measure $\mathrm{W}$, which is described next. ${ }^{127}$ After discussing Oakland's Measure W, this Note will explore past attempts by New York City to enact property tax regimes similar to Vancouver and Oakland.

\section{A. Oakland's Measure W}

Measure W, which passed in November 2018 with $70 \%$ of the vote, ${ }^{128}$ established a more limited form of the Vancouver Empty Home Tax. Chapter 4.56 of the Oakland, California Code of Ordinances establishes the "Vacant Property Tax." 129 Section 4.56.020 defines a vacant property as one "that is in use less than fifty (50) days during a calendar year," 130 which is far less stringent than the six-month standard used by Vancouver. Furthermore, Measure W says nothing about how the City of Oakland will determine and identify properties used less than fifty days out of the year. ${ }^{131}$

Section 4.56.030 lays out the tax: "[a] special tax in the amounts set forth below is hereby imposed on every vacant parcel of real property within the City, other than those exempted, as described below."132 Section 4.56.030(E) contains a table that details the maximum tax rate that can be assessed depending on the type of property. ${ }^{133}$ For example, a vacant residential property would be assessed US $\$ 6,000$ per parcel while a vacant condominium would be assessed US $\$ 3,000$ per parcel. ${ }^{134}$ The City Council has the power to lower these rates, but they cannot increase them. ${ }^{135}$ Some residents have argued that assessing a per parcel tax rate, unlike Vancouver

Pitt Tax Review | ISSN 1932-1821 (print) 1932-1996 (online) DOI 10.5195/taxreview.2020.124 | http://taxreview.law.pitt.edu 
which ties the tax to the assessed value of the property, leaves the vacant property tax charging more than their normal tax bill. ${ }^{136}$

Like Vancouver, Oakland's Measure W provides ample exemptions. ${ }^{137}$ These exemptions include: "very low income" owners, ${ }^{138}$ "exceptional specific circumstances [that] prevent the use or development" of the property, ${ }^{139}$ "property that is under active construction," 140 and others. However, Measure $\mathrm{W}$ has been criticized for not being clear about the parameters of these exemptions. ${ }^{141}$ For example, "exceptional specific circumstances prevent the use or development"142 is vague and only briefly explained within the statute. The statute offers examples of damage by natural disaster and an adjoining parcel used by property owners in conjunction with their residential parcel. ${ }^{143}$ An update to Measure W says that section $4.56 .030(\mathrm{~J})(1)(\mathrm{d})$ exemptions, for properties with exceptional specific circumstances, are at the sole discretion of the City Administrator, who may request and review all pertinent evidence. ${ }^{144}$ Additionally, the update only allows this exemption to last five years with the option to renew for five years with the approval of the City Administrator. ${ }^{145}$ At public hearings, city officials have stated that extreme slope, extreme fire risk, and other environmental factors will be considered under the exceptional circumstances exemption. ${ }^{146}$

\footnotetext{
${ }^{136}$ Katie Bernstein, Controversial Property Tax is Tabled After Public Outcry at City Council Meeting, OAKLANDNORTH (Oct. 16, 2019), https://oaklandnorth.net/2019/10/16/controversial-propertytax-is-tabled-after-public-outcry-at-city-council-meeting/.

${ }^{137}$ Oakland Vacant Property Tax, supra note 129, § 4.56.030(J).

${ }^{138} I d . \S 4.56 .030(\mathrm{~J})(1)(\mathrm{a})$.

${ }^{139} I d$. $\S 4.56 .030(J)(1)(d)$.

${ }^{140} I d . \S 4.56 .030(\mathrm{~J})(1)(\mathrm{e})$.

${ }^{141}$ See Tavares, supra note 126; Bernstein, supra note 136.

${ }^{142}$ Oakland Vacant Property Tax, supra note 129, § 4.56.030(J)(1)(d).

${ }^{143} \mathrm{Id}$.

${ }^{144} I d . \S 4.56 .090(\mathrm{D})$.

${ }^{145} \mathrm{Id}$.

${ }^{146}$ Bernstein, supra note 136.
}

Pitt Tax Review | ISSN 1932-1821 (print) 1932-1996 (online) DOI 10.5195/taxreview.2020.124 | http://taxreview.law.pitt.edu 


\section{8 |Pittsburgh Tax Review | Vol. 182020}

Complaints about the flat per parcel tax rate (US\$6,000 per vacant residential parcel; US\$3,000 per vacant condominium parcel) and the vague and hard-to-define exemptions led Oakland's City Council to table the property tax in October 2019. ${ }^{147}$ In December 2019, the City Council responded to these complaints by lowering the per parcel tax rate to US\$3,000 for smaller vacant lots. ${ }^{148}$ Starting in January 2020, Oakland city staff will notify owners of parcels that the city thinks are vacant. ${ }^{149}$ Automatic exemptions from the tax will include property that has been used more than fifty days out of the year, adjoining lots, and community gardens. ${ }^{150}$ The exceptional circumstances exemption will still apply for properties with severe slope or fire hazard concerns. ${ }^{151}$ The imposition of Measure W's tax will begin July 1,$2020 ;{ }^{152}$ thus, Oakland has not yet reported similar data as Vancouver.

\section{B. New York City's Attempts}

While it is too early to determine how successful Oakland's Measure W will be, other American cities have considered similar taxes, as well. ${ }^{153} \mathrm{New}$ York City saw vacant shopfront rates rise from $2.1 \%$ in 2012 to $4.2 \%$ in $2017 .{ }^{154}$ Gaudy penthouse sales have also fueled a desire for similar vacant

${ }^{147} I d$.

${ }^{148}$ Dan Kalb, Dan Kalb's December Newsletter, Dan Kalb OAKLAND CiTy COUnCIL (Dec. 23, 2019), http://www2.oaklandnet.com/oakca1/groups/citycouncil/documents/agenda/oak072658.pdf.

${ }^{149} \mathrm{Id}$.

${ }^{150} I d$.

${ }^{151} I d$.

${ }^{152}$ Measure $W \sim$ Authorizes a Tax to be Imposed on Vacant Property Beginning July 1, 2020 for Property Deemed Vacant in 2019, CITY OF OAKLAND (Nov. 22, 2019), https://www.oaklandca.gov/news/ 2019/measure-w-outreach-and-civic-engagement-forums.

${ }^{153}$ See Rich Calder, De Blasio: I Will Lobby for Vacancy Tax on Landlords of Empty Storefronts, N.Y. PosT (Jan. 9, 2019), https://nypost.com/2019/01/09/de-blasio-i-will-lobby-for-vacancy-tax-onlandlords-of-empty-storefronts/.

${ }^{154} I d$.

Pitt Tax Review | ISSN 1932-1821 (print) 1932-1996 (online) DOI 10.5195/taxreview.2020.124 | http://taxreview.law.pitt.edu 
property taxes. ${ }^{155}$ In addition, the rental vacancy rate sits at about $2 \% .{ }^{156}$ This is much lower than the rate reported by the Census Bureau (4.5\%), ${ }^{157}$ and indicates a market similar to that of Vancouver. However, the COVID-19 Pandemic has drastically changed the New York City rental market. ${ }^{158}$ Many wealthy New Yorkers left the city in an attempt to evade effects of the pandemic. ${ }^{159}$ Such an exodus has led to a significant increase in empty apartments. ${ }^{160}$ The rental market has more than 10,000 more vacant apartments on the market than this time last year while prices are down almost $4 \% .{ }^{161}$ Therefore, the need and wherewithal may make implementing a vacant property tax unlikely.

Additionally, mimicking Vancouver's tax may be difficult to implement. ${ }^{162}$ The City of Vancouver already required property owners to declare a Principal Residence, while New York City does not. ${ }^{163}$ However, New York City does have an income tax that exempts nonresidents who earn their income in the city; ${ }^{164}$ this could provide the necessary data for the city

${ }^{155}$ Nikita Stewart \& David Gelles, The \$238 Million Penthouse, and the Hedge Fund Billionaire Who May Rarely Live There, N.Y. TIMES (Jan. 24, 2019), https://www.nytimes.com/2019/01/24/ nyregion/238-million-penthouse-sale.html.

${ }^{156}$ John Schneider, Lessons from Vancouver for NYC's Debate Over Taxing Vacant Land to Ease Housing Crunch, CiTYLIMITS (Oct. 12, 2017), https://citylimits.org/2017/10/12/lessons-from-vancouverfor-nycs-debate-over-vacant-land/\# (explaining further that "[i]n some of Manhattan's most expensive buildings, as few as one third of owners claim the tax abatement for full-time [residents.]").

${ }^{157}$ U.S. CENSUS BUREAU, supra note 16.

${ }^{158}$ Robert Frank, Manhattan Rental Market Plunges, Leaving 15,000 Empty Apartments in August, CNBC (Sept. 10, 2020), https://www.cnbc.com/2020/09/10/manhattan-rental-market-plunges-leaving15000-empty-apartments.html.

${ }^{159}$ Tracey Tully \& Stacey Stowe, The Wealthy Flee Coronavirus. Vacation Towns Respond: Stay Away., N.Y. TiMES (Mar. 25, 2020), https://www.nytimes.com/2020/03/25/nyregion/coronavirus-leaving -nyc-vacation-homes.html.

${ }^{160}$ Frank, supra note 158.

${ }^{161} I d$.

${ }^{162}$ Schneider, supra note 156.

${ }^{163} \mathrm{Id}$.

${ }^{164}$ N.Y. STATE DeP'T OF TAX'N Fin., InDividual TAXPAYER ANSWER CTR., ANSWER ID 571 (Dec. 3, 2019), https://tax.custhelp.com/app/answers/detail/a_id/571/ /i-don\%E2\%80\%99t-live-in-newyork-city $\% 2 \mathrm{C}$-but-i-earn-income-there.-am-i-subject-to-a-new.

Pitt Tax Review | ISSN 1932-1821 (print) 1932-1996 (online) DOI 10.5195/taxreview.2020.124 | http://taxreview.law.pitt.edu 


\section{Pittsburgh Tax Review | Vol. 182020}

to determine a principal residence. Vancouver was able to create its Empty Home Tax utilizing the foundation of its Principal Residence program, which requires property owners to declare a principal residence in order to receive a school tax credit. ${ }^{165}$ Since Vancouver homeowners already declared their principal residence to receive the school tax credit, the City of Vancouver possessed solid data on which properties would be declared principal residences under the Empty Home Tax. ${ }^{166}$ This also had the added benefit of preventing the need to calculate occupancy for many properties. ${ }^{167}$ An additional difficulty would be getting the buy-in of state legislators in Albany; ${ }^{168}$ any empty home tax in New York City would have to be approved by the state government. ${ }^{169}$ Vancouver also required provincial government buy-in, ${ }^{170}$ but the province faced an extraordinary situation where all twentytwo suburban municipalities surrounding Vancouver also faced a housing crunch. ${ }^{171}$ British Columbia thus acted to amend Vancouver's charter to allow the Empty Home Tax. ${ }^{172}$ It is not clear that New York State would do the same for New York City. ${ }^{173}$

${ }^{165}$ Schneider, supra note 156.

${ }^{166} I d$.

${ }^{167}$ Id. (“' Our planning department looked at a number of international cities,' Lee says of the decision to use Principal Residence. 'Most of them have been based on the concept of occupancy, and length of occupancy, and their recommendation was, "That's not working." It's too hard to prove how long you were occupied."”).

${ }^{168} I d$.

${ }^{169} I d$. ("Any new tax, which would be the simplest way to implement a vacancy fee, would have to be approved by Albany, which has been known to resist any attempts by the city to control its own housing policy.").

${ }^{170} \mathrm{Id}$.

${ }^{171} I d$.

${ }^{172} I d$.

${ }^{173} I d$. ("This may seem unlikely at the moment, but given the international momentum of the idea, as well as the scope of the problem in New York City, where even the mayor concedes there are no easy solutions, it may not be long before a vacancy tax starts to look like a good idea.").

Pitt Tax Review | ISSN 1932-1821 (print) 1932-1996 (online) DOI 10.5195/taxreview.2020.124 | http://taxreview.law.pitt.edu 
Furthermore, past efforts to enact pied-à-terre laws in New York City have failed. ${ }^{174}$ Pied-à-terre laws would tax high-value properties that are not principal residences, ${ }^{175}$ which would largely accomplish the same thing as Vancouver's Empty Home Tax. The bill, originally proposed in 2014, did not pass. ${ }^{176}$ After failing to garner much attention in 2014, politicians found a groundswell of support for pied-à-terre laws in $2019 .{ }^{177}$ However, the real estate industry quickly lobbied to forestall the bill. ${ }^{178} \mathrm{New}$ York's failure to enact pied-à-terre laws indicates a tough road for any sort of vacancy tax that would presumably attempt to tax more properties than a pied-à-terre law would.

\section{AMERICAN PROPERTY LAW AND TAX JURISPRUDENCE}

Property ownership has never meant that the owner gets to do whatever they want to the property whenever they want to. Often rights are taken away or added to property. For example, over the last century zoning has been deemed a reasonable application of a municipality's police power. ${ }^{179}$ In Village of Euclid, Ohio v. Ambler Realty Co.,${ }^{180}$ the U.S. Supreme Court held that the Village of Euclid could use its police powers to enact zoning regulations to prevent places of business from causing a nuisance to private homes. Nectow v. City of Cambridge further clarified that zoning decisions will not be set aside unless the zoning ordinances are clearly "arbitrary or irrational." ${ }^{181}$ With this precedent, it is not farfetched that a court would see

\footnotetext{
${ }^{174}$ Valeria Ricciulli, Pied-à-Terre Tax on Pricey New York Real Estate Could Be Revived, CURBED N.Y. (Sept. 12, 2019), https://ny.curbed.com/2019/9/12/20862577/pied-a-terre-tax-luxury-real-estatenyc-mansion.

${ }^{175} \mathrm{Id}$.

${ }^{176}$ S. S7941, 2013-14 Leg. Sess. (N.Y. 2014).

${ }^{177}$ Vivian Wang, N.Y. Had a Plan for a 'Pied-à-Terre' Tax on Expensive Homes. The Real Estate Industry Stopped It., N.Y. TIMES (Mar. 29, 2019), https://www.nytimes.com/2019/03/29/nyregion/pieda-terre-tax.html.

${ }^{178} I d$.

${ }^{179}$ See Nectow v. City of Cambridge, 277 U.S. 183 (1928); Village of Euclid, Ohio v. Ambler Realty Co., 272 U.S. 365 (1926).

${ }^{180}$ Village of Euclid, Ohio, 272 U.S. at 396-97.

${ }^{181}$ Nectow, 277 U.S. at $187-88$ ("We quite agree with the opinion expressed below that a court should not set aside the determination of public officers in such a matter unless it is clear that their action
}

Pitt Tax Review | ISSN 1932-1821 (print) 1932-1996 (online) DOI 10.5195/taxreview.2020.124 | http://taxreview.law.pitt.edu 


\section{2 |Pittsburgh Tax Review | Vol. 182020}

a similar rationale for penalizing property owners who do not participate in the rental market.

There are no United States Constitutional impediments to an empty home tax. In National Federation of Independent Business v. Sebelius, the Court held that the federal government's Affordable Care Act penalty was a constitutional use of the federal government's power to tax. ${ }^{182}$ Therefore, the federal government could tax noninvolvement in a market. ${ }^{183}$ The federal government could not compel involvement in the market, but it could tax citizens who did not participate in the market. This seems analogous to an empty home tax. An empty home tax purports to tax property owners who are not participating in the rental market. This taxation of nonparticipation would be similar to the taxing of nonparticipation in the health insurance market.

This theory of taxing nonparticipants in markets at the federal level may be extended to state property taxation via the U.S. Supreme Court's historical preference not to interfere with state taxes. ${ }^{184}$ For the most part, the Court has validated property taxes. ${ }^{185}$ In the instances where the Court overrules property taxes, the deficiencies lie in due process in the assessment process ${ }^{186}$ and equal protection. ${ }^{187}$ Thus, the failures arise more in the drafting of the law than the actual ability to tax property. ${ }^{188}$ Therefore, an empty home tax, or its equivalent, would most likely be constitutional as a tax on a nonparticipant in the U.S. rental market.

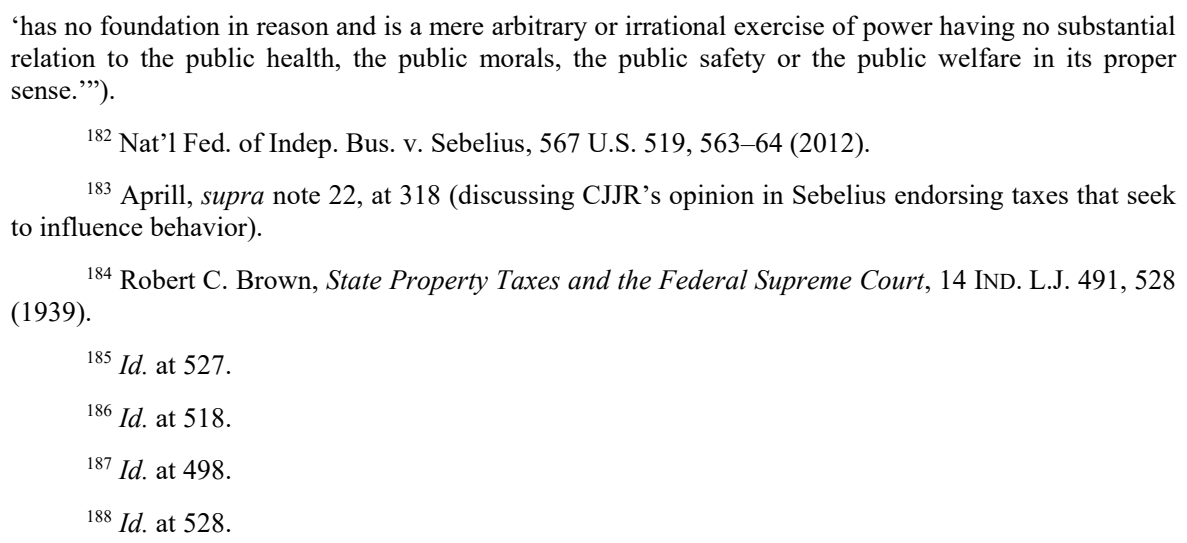
relation to the public health, the public morals, the public safety or the public welfare in its proper sense."').

${ }^{182}$ Nat'l Fed. of Indep. Bus. v. Sebelius, 567 U.S. 519, 563-64 (2012).

${ }^{183}$ Aprill, supra note 22, at 318 (discussing CJJR's opinion in Sebelius endorsing taxes that seek to influence behavior). (1939).

${ }^{184}$ Robert C. Brown, State Property Taxes and the Federal Supreme Court, 14 IND. L.J. 491, 528

${ }^{185} \mathrm{Id}$. at 527.

${ }^{186} I d$. at 518.

${ }^{187}$ Id. at 498.

${ }^{188}$ Id. at 528.

Pitt Tax Review | ISSN 1932-1821 (print) 1932-1996 (online) DOI 10.5195/taxreview.2020.124 | http://taxreview.law.pitt.edu 


\section{SUGGESTED TAX STRUCTURE}

\section{A. Property Tax}

Given that an empty home tax is most likely legal, and often complex, what is the best structure for the tax? It is understandable that government officials might want to attempt to control housing prices, ease tight rental markets, and use revenues to support low-income housing initiatives. Some economists-such as Enid Slack, Director of the Institute on Municipal Finance and Governance at the University of Toronto's Munk School of Public Policy - tout residential property taxes as an excellent means for municipalities to achieve these goals. ${ }^{189}$ Residential property taxes are viewed as fair, tough to flout, and provide a certain amount of selfsufficiency for municipalities. ${ }^{190}$ American municipalities largely act in accordance with this train of thought; approximately $70.9 \%$ of American local tax revenues come from real property taxes. ${ }^{191}$

While economists may vocally support property taxes, ${ }^{192}$ issues still arise around equity and transparency. ${ }^{193}$ For example, if the property tax is meant to tax a homeowner for their use of the property, then the tax is regressive. ${ }^{194}$ This is because low-income homeowners have a higher percentage of their income captured by the property tax. ${ }^{195}$ On the other hand, if a property tax is meant to help localities capture capital gains on property,

189 Enid Slack, The Property Tax-in Theory and Practice, IMFG PAPERS ON Mun. Fin. \& GOVERNANCE 2011, at 1 .

${ }^{190} I d$. at 2.

${ }^{191} I d$. at 9 .

${ }^{192}$ Tracy Gordon, Critics Argue the Property Tax is Unfair. Do They Have a Point, TAX POL'Y CTR. (Mar. 9, 2020), https://www.taxpolicycenter.org/taxvox/critics-argue-property-tax-unfair-do-theyhave-point (citing to Justin Fox, Why Economists Love Property Taxes and You Don't, BloomBerG (Nov. 28, 2018), https://www.bloomberg.com/opinion/articles/2017-11-28/why-economists-loveproperty-taxes-and-you-don-t.).

$$
\begin{aligned}
& { }^{193} I d . \\
& { }^{194} I d . \\
& { }^{195} I d .
\end{aligned}
$$

Pitt Tax Review | ISSN 1932-1821 (print) 1932-1996 (online) DOI 10.5195/taxreview.2020.124 | http://taxreview.law.pitt.edu 


\section{4 | Pittsburgh Tax Review | Vol. 182020}

then a property tax is progressive. ${ }^{196}$ High-income owners will realize more capital gains on their property, on average, than low-income property owners; thus, the tax would be more equitable when framed this way. ${ }^{197}$ Furthermore, property taxes expose homeowners to uncertainty beyond their control: housing prices vary in ways that are much more difficult to predict than a homeowner's salary or a homeowner's exposure to a sales tax. ${ }^{198}$ Municipalities that face significant changes to their tax base may be quick to reassess property taxes. ${ }^{199}$ On top of that, reassessment practices can be mired with difficulties of their own, including delayed appraisals and high-income property owners having a higher success rate in the appeal process. ${ }^{200}$

Municipalities also face risks from relying on property taxes. For example, in 1994, Michigan voters approved Proposal A, which allowed annual property tax increases to grow by the lesser of inflation or 5\%. ${ }^{201}$ After the Great Recession, many Michigan communities were facing steep declines in property values. ${ }^{202}$ By 2017, Detroit property values still registered US\$3.7 billion below pre-recession highs. ${ }^{203}$ This means property owners enjoying lower property taxes while leaving cities strapped for funding. ${ }^{204}$

Thus, property taxes, while perhaps theoretically ideal, face many practical limitations. Because of these limitations, municipalities struggle to implement property taxes for many reasons. Politically, property taxes are very unpopular. ${ }^{205}$ Unlike income taxes, which benefit from some invisibility

${ }^{201}$ Jonathan Oosting, Property Tax Hole Spurs Proposal A Reform, The Detroit News (Mar. 4, 2019), https://www.detroitnews.com/story/news/politics/2019/03/04/michigan-proposal-a-property-

${ }^{202} I d$.

${ }^{203} \mathrm{Id}$.

${ }^{204} I d$.

${ }^{205}$ Slack, supra note 189 , at 7.
} taxes/2954723002/.

Pitt Tax Review | ISSN 1932-1821 (print) 1932-1996 (online) DOI 10.5195/taxreview.2020.124 | http://taxreview.law.pitt.edu 
via withholding, property taxes are highly visible. ${ }^{206}$ Additionally, property owners cannot exert meaningful control over the market value of their property or when a municipality decides to reassess property values. ${ }^{207}$ These factors also make property taxes inelastic - home values are not often extremely volatile, but rather gradually increase or decrease over time. ${ }^{208}$ Delays in reassessing property values also cause a lag in property tax revenue, ${ }^{209}$ as homeowners enjoy tax rates at the lower, previously assessed market value. Furthermore, property taxes are full of exemptions, like the Vancouver Empty Home Tax, and incentives that erode the tax base. ${ }^{210}$ In order to cover for these losses, a municipality would have to charge higher tax rates to property owners who do not benefit from exemptions or incentives, which would make property taxes even more unpopular. ${ }^{211}$ Finally, inconsistent assessments lead to poor administrability, which in turn lowers the revenue from property taxes and also lowers their popularity. ${ }^{212}$

Paul Kershaw, a professor at the School of Population and Public Health at the University of British Columbia, in a paper discussing a switch in tax policy from predominately earnings to predominately housing wealth, suggests an additional tax on all property valued at C\$1 million or more. ${ }^{213}$ Such a tax would apply to approximately $20 \%$ of homes in British Columbia. ${ }^{214}$ If home values remain unchanged, Kershaw estimates the tax would net $\mathrm{C} \$ 3$ billion in tax revenue. ${ }^{215}$ Kershaw chose the C $\$ 1$ million threshold for multiple reasons: (1) a $\mathrm{C} \$ 1$ million house would put the homeowner in the wealthiest 1\% worldwide; (2) a C\$1 million house is four

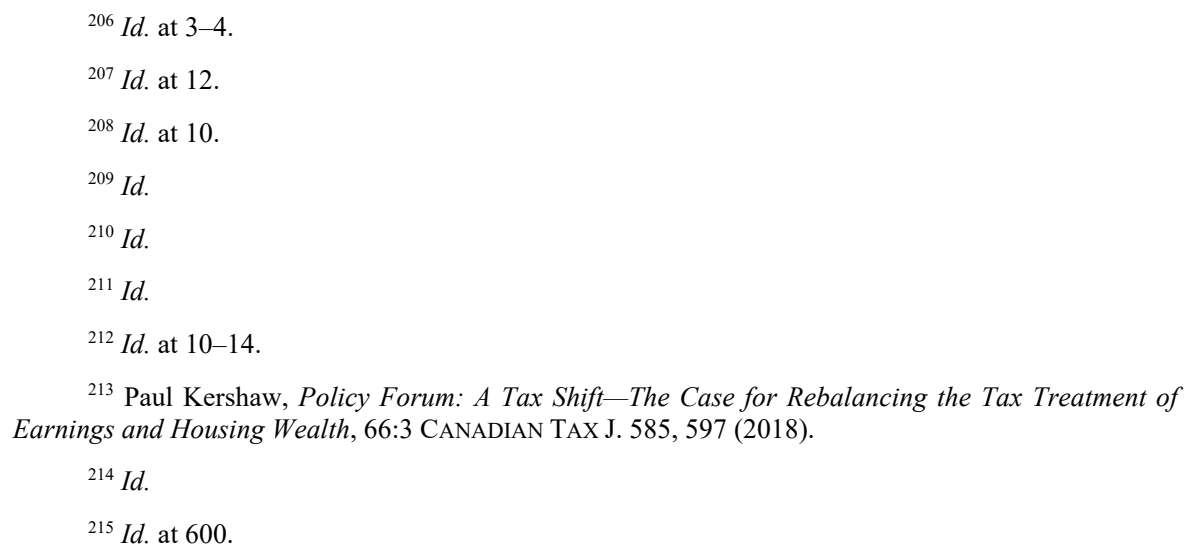

Pitt Tax Review | ISSN 1932-1821 (print) 1932-1996 (online) DOI 10.5195/taxreview.2020.124 | http://taxreview.law.pitt.edu 


\section{$216 \mid$ Pittsburgh Tax Review | Vol. 182020}

times the average price of a house forty years ago; (3) $80 \%$ of British Columbia households would be exempt from the tax; and (4) the high revenue potential mentioned above. ${ }^{216}$ Kershaw further enumerates four considerations for developing and implementing a $\mathrm{C} \$ 1$ million property tax: (1) deferability, (2) progressivity, (3) supply, and (4) a revenue target. ${ }^{217}$

Kershaw argues that a C\$1 million property tax should come with the option to defer payment. ${ }^{218}$ This would prevent undue burdens to "houserich, cash-poor" residents. ${ }^{219}$ Property owners who elect to defer would be charged interest to cover for the municipality likely borrowing to make up the lost revenue from the deferral. ${ }^{220}$ Deferral only adds to an already difficult-to-administer tax, though; the administrability of property taxes is already an issue that Slack addresses in her article. ${ }^{221}$ Deferrals would create difficult situations and tough determinations when a homeowner dies with deferred taxes owed. Would the deferred tax bill automatically come due? Could the inheritor continue to defer taxes ad infinitum? In addition to these questions, exemptions and deferrals erode the tax base. ${ }^{222}$

Kershaw further argues that the $C \$ 1$ million property tax should be progressive. ${ }^{223}$ Owners of $\mathrm{C} \$ 1$ million properties should not be able to credit other taxes paid toward their new property tax. ${ }^{224}$ The $\mathrm{C} \$ 1$ million tax should also incentivize building new properties in an effort to drive down property values by adding new properties to the market supply. ${ }^{225}$ To this end, Kershaw recommends an exemption to encourage the development of rental

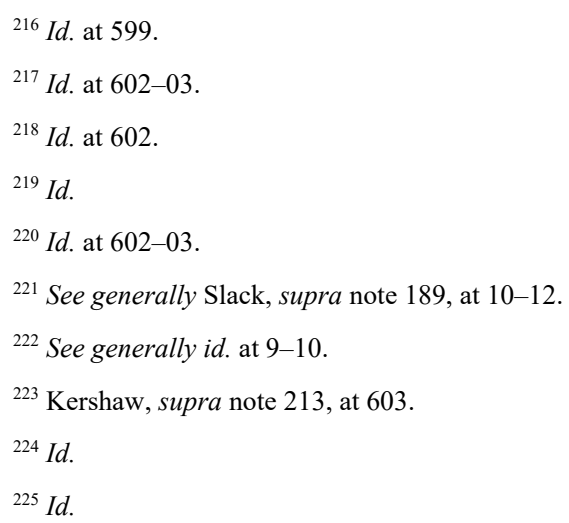

Pitt Tax Review | ISSN 1932-1821 (print) 1932-1996 (online) DOI 10.5195/taxreview.2020.124 | http://taxreview.law.pitt.edu 
buildings. ${ }^{226}$ Finally, any new property tax should strive to return the ratio of property taxation to GDP to what the ratio was decades ago. ${ }^{227}$ This prevents the young purchasers who bought homes back then from realizing a windfall today. $^{228}$

These are important considerations for redeveloping Vancouver's real property taxes. First, the tax should not focus on just empty residences; instead, the tax should be an additional levy on all properties over $\$ 1$ million. As Kershaw noted, the revenue capabilities of such a tax would be great. ${ }^{229}$ However, exemptions and deferrals erode the tax base, as explained by Slack. ${ }^{230}$ Thus, the Vancouver Empty Home Tax should be remade with limited exemptions and should not adopt Kershaw's suggested deferral. For example, the Vancouver Empty Home Tax should, at a minimum, consider removing the renovation exemption. This exemption has proved clunky and hard to administer as evidenced by ongoing lawsuits. ${ }^{231}$ The renovation exemption further erodes the available rental market because property owners must temporarily move out of renovated residences into leased residences. Furthermore, the renovation exemption harms the progressivity of the tax, as only wealthy property owners can afford the type of renovations that require moving to a second property. Excessive exemptions and deferrals address the unpopularity of property taxes, yet these mechanisms create a framework in which tax revenue is lost and must be made up elsewhere. As Kershaw noted, the property tax ought to be progressive. From this perspective, Oakland's per-parcel rate is inferior to Vancouver's flat-rate percentage of property value. Still, Vancouver's excessive exemptions hurt the progressivity of the tax as landowners are given ample opportunity to evade the tax. Taxing all properties valued at over $\$ 1$ million, instead of Vancouver's current focus on empty homes, would offer better progressivity, a method to cool the city's housing market, and a more consistent source of

$$
\begin{aligned}
& { }^{226} I d . \\
& { }^{227} I d . \\
& { }^{228} I d . \\
& { }^{229} \text { Id. at } 599 . \\
& { }^{230} \text { See Slack, supra note } 189 . \\
& { }^{231} \text { Fraser, supra note } 84 .
\end{aligned}
$$

Pitt Tax Review | ISSN 1932-1821 (print) 1932-1996 (online) DOI 10.5195/taxreview.2020.124 | http://taxreview.law.pitt.edu 


\section{8 |Pittsburgh Tax Review | Vol. 182020}

revenue to address low- and middle-income housing. However, homeowners must have limited to no chance of using exemptions; otherwise, the progressivity is in name only.

Allowing exemptions for rental developments sounds good on paper, but much work would have to be done to ensure that the properties developed are not high-end, luxury apartments or condominiums. ${ }^{232}$ Instead of exemptions, municipalities could use the revenue from the tax to partner with developers creating developments in line with the regional vision for affordable housing. Furthermore, in theory, higher taxes alone would discourage investment in high-end realty and lower property values. In this way, municipalities should consider the power of taxation as a fiscal policy matter. Tax cuts can accelerate asset value growth while tax increases can slow asset value growth. Much like central banks use monetary policy to control inflation and employment, so should municipalities control housing values with property taxes. When Vancouver is in a hot real estate market, city officials should act to cool the market and prevent it from overheating by taxing high-end realty at greater rates. When Vancouver real estate cools off, city officials should consider toggling down property taxes to encourage investment and growth. Housing bubbles may be inevitable in the long run, ${ }^{233}$ but municipalities that can effectively deploy all fiscal policy tools available will help mitigate the disastrous effects of those bubbles. A municipality that effectively, and cautiously, adjusts property taxes on high-value properties can deter explosive growth or encourage investment via clear communication of intent and duration of the tax. ${ }^{234}$ The goal should not be to prevent bubbles entirely, but instead to manage the bubble through a municipality's stalwart dedication to monitoring the local real estate market.

In summary, the Vancouver Empty Home Tax is superior to Oakland's Measure $\mathrm{W}$ and other American attempts, but the tax has room for

${ }^{232}$ See Janet Stearns, The Low-Income Housing Tax Credit: A Poor Solution to the Housing Crisis, 6 YALE L. \& PoL'Y REV. 203, 228 (1988) (arguing that the Low-Income Housing Tax Credit will not induce development of affordable housing).

${ }^{233}$ See AlAN S. BLINDER, AfTER THE MUSIC STOPPED 265 (2014) ("If so, stamping out bubbles is a loser's game. So maybe we should focus on something more achievable-such as reducing the frequency or magnitude of bubbles, or limiting the damage when they burst.").

${ }^{234}$ See generally BEN S. BERnANKe, THE COURAGE TO ACt 504 (2017) (“Tight fiscal policies were arguably offsetting much of the effect of our monetary efforts.").

Pitt Tax Review | ISSN 1932-1821 (print) 1932-1996 (online) DOI 10.5195/taxreview.2020.124 | http://taxreview.law.pitt.edu 
improvement. Instead of focusing on empty homes, the tax should focus on all properties valued at $\$ 1$ million or more. Furthermore, the tax should severely limit the availability of exemptions and should not permit deferral of the tax.

\section{B. Alternative Tax Options}

\section{Wealth Tax}

In her 2020 presidential primary campaign, Elizabeth Warren touted a wealth tax as a possible solution to rising inequalities. ${ }^{235}$ Dubbed "The UltraMillionaires Tax," the tax would levy a $2 \%$ rate on households with more than US $\$ 50$ million in net worth and a $6 \%$ rate on households with over US $\$ 1$ billion in net worth. ${ }^{236}$ To determine a household's net worth, a wealth tax would require totaling the fair market value of all assets less the fair market value of all liabilities. ${ }^{237}$ A broad definition of assets would allow a wealth tax to capture net worth in the form of private equity, fixed income, and real estate. ${ }^{238}$ Experts estimate that a broadly defined wealth tax could bring in approximately US $\$ 2.75$ trillion in tax revenue over ten years, ${ }^{239}$ and they tout the wealth tax as one of the most powerful means of solving economic inequality. ${ }^{240}$

Increasing federal revenue via a wealth tax may negate a municipality's need to utilize property taxes to control rental markets. Instead, wealth taxes could be redistributed to municipalities to build, maintain, and fund affordable housing. ${ }^{241}$ However, wealth taxes do come with some risk,

\footnotetext{
${ }^{235}$ Huaqun Li \& Karl Smith, Analysis of Sen. Warren and Sen. Sanders' Wealth Tax Plans, TAX FOUND. (Jan. 27, 2020), https://taxfoundation.org/wealth-tax/.

${ }^{236} I d$. at 2.

${ }^{237} I d$. at 3 .

${ }^{238} \mathrm{Id}$.

${ }^{239} I d$. at 9 .

${ }^{240}$ Emmanuel Saez \& Gabriel Zucman, Progressive Wealth Taxation, BROOKINGS PAPERS ON ECON. ACTIVITY (Sept. 5, 2019), https://www.brookings.edu/wp-content/uploads/2019/09/Saez-Zucman _conference-draft.pdf.

${ }^{241}$ See generally Sen. Elizabeth Warren, Safe and Affordable Housing, WARREN DEMOCRATS (Mar. 16, 2019), https://elizabethwarren.com/plans/safe-affordable-housing (advocating for lowering the
}

Pitt Tax Review | ISSN 1932-1821 (print) 1932-1996 (online) DOI 10.5195/taxreview.2020.124 | http://taxreview.law.pitt.edu 


\section{0 |Pittsburgh Tax Review | Vol. 182020}

including: (1) administrability, ${ }^{242}$ (2) liquidity issues, ${ }^{243}$ and (3) taxpayer flight. ${ }^{244}$ For example, many assets are not traded on a public market, which creates difficulty in determining an asset's true fair market value. ${ }^{245}$ Furthermore, capital assets are increasingly mobile. ${ }^{246}$ The combination of hard-to-assess fair market value and easily mobile assets make administration of a wealth tax difficult. ${ }^{247}$ The modern mobility of assets extends to the millionaires and billionaires themselves. ${ }^{248}$ After France enacted a wealth tax, many millionaires fled the country and relocated somewhere else. ${ }^{249}$

While a wealth tax may be a terrific way for the federal government to solve the housing crisis nationwide, these issues may present an insurmountable barrier at the municipal level. For one, asking municipal governments to value overly complex assets would divert huge amounts of resources. Second, wealthy property owners could easily skip town and move a city away. Inducing wealthy homeowners to move may free up real property, but it could crater demand as well. Finally, a wealth tax at the federal level does not necessarily solve all housing issues on the microlevel. A municipality is better suited to understanding, controlling, and maintaining its housing market on a neighborhood-by-neighborhood basis. A federal

threshold for the Estate Tax, a type of wealth tax, to a ported \$7 million to fund investment in affordable housing).

${ }^{242}$ Li \& Smith, supra note 235.

${ }^{243} \mathrm{OECD}$, The Role and Design of Net Wealth Taxes in the OECD, OECD TAX POL'Y STUDIES, No. 26, 64 (2018), https://read.oecd-ilibrary.org/taxation/the-role-and-design-of-net-wealth-taxes-in-theoecd_9789264290303-en\#page3.

${ }^{244} \mathrm{Id}$. at 66.

${ }^{245} \mathrm{Li} \&$ Smith, supra note 235, at 7 (estimating that only "one-fifth of the assets held by the top 1 percent" are publicly traded on exchanges).

${ }^{246}$ OECD, supra note 243 , at 67.

${ }^{247} \mathrm{Id}$.

${ }^{248}$ Greg Rosalsky, If a Wealth Tax is Such a Good Idea, Why Did Europe Kill Theirs?, NPR (Feb. 26, 2019), https://www.npr.org/sections/money/2019/02/26/698057356/if-a-wealth-tax-is-such-agood-idea-why-did-europe-kill-theirs.

${ }^{249} I d$.

Pitt Tax Review | ISSN 1932-1821 (print) 1932-1996 (online) DOI 10.5195/taxreview.2020.124 | http://taxreview.law.pitt.edu 
wealth tax takes tools out of the hands of the municipality, who knows the market best, and vests the power in the hands of the federal government.

Furthermore, many argue that a federal wealth tax would be labeled a "direct tax," and thus must be apportioned across states based on state population; any plan that does not follow this requirement would be unconstitutional. ${ }^{250}$ Alternatively, a state level wealth tax could solve the constitutionality issue while also combating the taxpayer mobility problem. ${ }^{251}$ Taxpayers may find it easy to move from municipality to municipality but would be less likely to flee a state. Presumably, a state would have a better understanding of statewide rental markets than the federal government, but even then, the municipality would possess the most accurate and up-to-date information. Fiscal policy cannot be a stagnant, unused tool against bubbles and doldrums; instead, municipalities should have the power to adequately control their own housing markets.

\section{Value Added Tax}

In his 2020 presidential primary campaign, Andrew Yang advocated for a value-added tax (VAT). ${ }^{252}$ The VAT works by taxing transactions on goods and services throughout the supply chain. ${ }^{253}$ Yang's proposal included a $10 \%$ VAT, with proceeds going to fund his proposed Freedom Dividend, which would provide $\$ 1,000$ per month in universal basic income (UBI) to every American adult. ${ }^{254}$

The VAT is lauded for its ease-of-use and its capture of corporate earnings. ${ }^{255}$ Yang claimed that his VAT would prevent big technology companies, like Amazon and Google, from avoiding taxes by funneling

${ }^{250}$ Daniel Hemel \& Rebecca Kysar, The Big Problem With Wealth Taxes, N.Y. Times (Nov. 7, 2019), https://www.nytimes.com/2019/11/07/opinion/wealth-tax-constitution.html.

${ }^{251} I d$.

${ }^{252}$ Andrew Yang, Value-Added Tax, YANG2020, https://www.yang2020.com/policies/valueadded-tax/ (last visited July 29, 2020).

${ }^{253} \mathrm{Id}$.

${ }^{254} I d$.

${ }^{255} \mathrm{Id}$.

Pitt Tax Review | ISSN 1932-1821 (print) 1932-1996 (online) DOI 10.5195/taxreview.2020.124 | http://taxreview.law.pitt.edu 


\section{2 |Pittsburgh Tax Review | Vol. 182020}

assets around the world. ${ }^{256}$ Unlike the wealth tax (in certain instances), a VAT is harder to dodge. ${ }^{257}$ Furthermore, the VAT brings in revenue via consumption, ${ }^{258}$ without passing much cost onto the consumer. ${ }^{259}$ An International Monetary Fund working paper concluded that, on average, only about a third of a VAT's costs ultimately get passed on to the consumer price. ${ }^{260}$ On the other hand, critics argue that the VAT is regressive, creates inflation, and does not offer an easy means of toggling up taxes during booms or reducing taxes during busts. ${ }^{261}$ Since a VAT is essentially a consumption tax, citizens of all income levels bear the same burden, thus creating a regressive tax. ${ }^{262}$ Inflation could occur as costs are added into the supply chain; however, consumers would not cover the full amount of the cost. ${ }^{263}$ Because a VAT mirrors a sales tax enmeshed in the supply chain, the tax would not be easily adjusted to the current economic climate.

Using a federal VAT to finance UBI could ease housing issues by injecting capital into the hands of the consumers and allowing the consumer to use the capital how they see fit. However, like the wealth tax, this takes important fiscal policy techniques out of the hands of the municipality. On the other hand, a combination of the VAT and a municipal level tax on \$1 million plus properties could still be effective. In this way, consumers receive funds to spend on housing should they choose to, and municipalities maintain fiscal policy techniques to control their housing markets. As municipalities exercise this control, they can earmark tax revenue toward building, maintaining, and incentivizing affordable housing.

\footnotetext{
${ }^{256} \mathrm{Id}$.

${ }^{257} \mathrm{Id}$.

${ }^{258}$ Scott A. Hodge, From the Tax Foundation Archives: The Pros and Cons of a Value Added Tax (VAT), TAX FOUND. (Feb. 9, 2017), https://taxfoundation.org/pros-cons-value-added-tax-vat/.

${ }^{259}$ Yang, supra note 252.

${ }^{260}$ Dora Benedek et al., Estimating VAT Pass Through 16 (Int'l Monetary Fund, Working Paper

${ }^{261}$ Hodge, supra note 258.

${ }^{262} I d$.

${ }^{263}$ Yang, supra note 252; see also Alina Carare \& Stephan Danninger, Inflation Smoothing and the Modest Effect of VAT in Germany 17 (Int'l Monetary Fund, Working Paper 08/175, July 2008) (finding that a German VAT increase resulted in $73 \%$ of costs being passed on to consumers); see generally
} $15 / 214,2015)$. Benedek, supra note 260.

Pitt Tax Review | ISSN 1932-1821 (print) 1932-1996 (online) DOI 10.5195/taxreview.2020.124 | http://taxreview.law.pitt.edu 


\section{Applicability to Municipal Control of Rental Markets}

No one tax will offer a magic cure-all to an affordable housing crisis. Nevertheless, governments should invest in municipalities, who have the best ability to understand their real estate market and the municipalities' fiscal policy. A \$1 million plus property tax with limited exemptions allows a municipality to gain revenue, invest in affordable housing, and dampen booming markets. Vancouver's Empty Home Tax may have limited or unexciting results as of now, but empowering municipalities to avoid housing bubbles is the right move. Thus, while a VAT or wealth tax at the federal level may prove beneficial down the road, if the goal is to control a local real estate market, then the flexibility of a local property tax is ideal.

\section{CONCLUSION}

In conclusion, American jurisdictions face many political and legal hurdles in attempting to enact legislation like Vancouver's Empty Home Tax. ${ }^{264}$ Nevertheless, Vancouver's foray into taxing vacant properties offers many lessons, especially when compared to Oakland's more complicated enactment of a similar tax. First and foremost, Vancouver's rollout of the tax has not been smooth. Vancouver has amended the Empty Home Tax four times since its enactment in 2016. ${ }^{265}$ Municipalities looking to mimic Vancouver should carefully review the amendments, which often change or add definitions, exemptions, and processes. Vancouver may have enacted an unnecessarily cumbersome bill that could have been simplified via clearer and fewer exemptions. Still, Vancouver has seen a decent amount of revenue from the Empty Home Tax. Vancouver's tax of 1\% (now 1.25\%) of fair market value is preferable to Oakland's flat per parcel rate. Vancouver's tax is more equitable to property owners.

Raising revenue to dedicate to the rental squeeze is noble, but the stated goal is to return rental properties to the market. Vancouver's data suggests some success there as well, whereas Oakland's tax focuses on vacant land. Therefore, Vancouver's tax is preferable for returning unused, existing

\footnotetext{
${ }^{264}$ See Wang, supra note 177; Bernstein, supra, note 136.

${ }^{265}$ See VanCouver, B.C., BY-Law No. 12628 (Jan. 21, 2020); VanCouver, B.C., BY-Law No. 12396 (Mar. 12, 2019); VANCOUVER, B.C., BY-LAW No. 12287 (Oct. 30, 2018); VANCOUVER, B.C., BYLAW No. 11855 (July 11, 2017).
}

Pitt Tax Review | ISSN 1932-1821 (print) 1932-1996 (online) DOI 10.5195/taxreview.2020.124 | http://taxreview.law.pitt.edu 


\section{4 | Pittsburgh Tax Review | Vol. 182020}

properties to the rental market, whereas Oakland's tax attempts to encourage development of vacant land. Vancouver also benefited from a system that already tracked principal residences; an American city without such a tracking system may find it difficult to implement a similar tax. Additionally, Vancouver benefited from buy-in from its province; some municipalities, like New York City, may have more difficulty getting buy-in from their state legislatures. Municipalities looking at the successes of Vancouver's Empty Home Tax should be careful to review the negatives as well (like the lawsuits; rentals marketed to college students; and bumpy implementation process); however, Vancouver's version of the tax is much more preferable to Oakland's version.

The ideal version of the tax, which would empower municipalities to control overheating or underperforming real property markets, would levy an additional, flexible surcharge on all real properties valued over US $\$ 1,000,000$ with limited exemptions. Such a tax would allow municipalities to toggle up the tax during periods of overheating as well as to toggle down when the municipality wants to encourage investment. In this way, the municipality can attempt to avoid dangerous housing bubbles while using proceeds to enact an affordable housing program. Flexible additional real property taxes focused on high-net-worth property will not solve housing crunches on their own, but such taxes will offer a strong tool to be used in tandem with other methods.

Pitt Tax Review | ISSN 1932-1821 (print) 1932-1996 (online) DOI 10.5195/taxreview.2020.124 | http://taxreview.law.pitt.edu 